\title{
The Methodical Model of Teaching Songs by Ear and Its Effects on the Development of Students' Vocal Abilities
}

\author{
Biljana Jeremić and Emilija Stanković ${ }^{2}$ \\ 'University of Novi Sad, Faculty of Education in Sombor \\ 2University of Novi Sad, Academy of Arts
}

\section{Abstract}

The purpose of this paper was to verify the studied phenomenon (application of the vocal warm up exercises model, as well as the designed and planned methodical approach to learning songs by ear) by using an experiment with parallel groups. The subject of this study was to determine whether it was possible to influence the quality of singing and develop the vocal skills of younger school age students by implementing a planned and directed methodical approach to learning songs by ear. In order to check the effects of the implementation of the methodical model, the SAVS instrument (Scale for the Assessment of Vocal Skills, Jeremić, 2011, p. 281) was used, subtests I, II, III, IV and $V$ (with equivalent forms for the initial and final assessment). In the comparison of groups in relation to vocal skills, a general linear model was used, and in particular a multivariate analysis of covariance with repeated measures (MANCOVA with repeated measures). The sample of this research consisted of second grade students of elementary schools in Sombor and Kikinda, Serbia. The tests of within subject effects showed that the two groups differed in their level of vocal skills, when the average of the two measurements was observed $F(1)=11.424, p=.001$.

Key words: methods; music education; singing; younger school age pupils

\section{Introduction}

Performance of music by singing songs by ear primarily represents a vocal ability to respond to musical stimuli. A child's response to music is viewed through the development of "musical perception, cognitive musical development, affective development of vocal 
responses and the motor components of musical development" (Radoš-Mirković, 1998). "Given that the child's musical development takes place in the framework of their overall development, it is important to know the laws that govern it, in order to adapt the musical development and teaching to the child's individual abilities and needs" (Bačlija Sušić, 2015, p. 35). It is also of great importance that the future teacher is able to properly use and apply the methodical procedures of adopting a song by ear. As stated by Jurkic-Sviben and Margetić (2013, p. 112),

"In order to introduce the art of music to present-day children through music, a modern teacher is expected to possess the knowledge of musical elements and methodological procedures required to raise and educate future devotees of culture and this type of art by employing music and with music itself.'

Discussing the importance of performing music by singing by ear, Woody (2012) emphasizes the idea that the performance of music by ear represents the basis of skills that contribute to other aspects of music production, including improvisations, some forms of reading and performance by memory. Welch (2005) believes that the performance of music by singing is one of the characteristics that define humankind. Reviewing the significance of singing, the said author emphasizes the ontogenetic development of voice and the physical activity of voice in the context of anatomy and physiology, which are shaped within the framework of biological maturation, experience, cultural habits and tradition. The author Jarjisian (1981) points out, in her doctoral dissertation, that singing songs by heart leads to improvements in the performance of accurate tonal heights in children, both of the diatonic and pentatonic melodic strings.

By reviewing the relevant literature concerning the studies in the teaching of Music Education that deal with the vocal skills of younger school age students, it can be noticed that this field of research is underrepresented. The reasons for this should be sought in the fact that, as pointed out by Radoš (2010), musicians are not competent enough to engage in scientific research, and psychologists are not competent enough to deal with music-related issues. The phenomenon of performing music by singing and the reactions to this phenomenon are very complex and variable, and their objective observation and measurement is therefore hindered and conditioned by certain problems. The presented scales or measuring instruments examine only individual segments of vocal skills: intonation precision, vocal range, accurate reproduction of melody, but not the physical components of the voice, of what the voice can produce. A child may hear that he or she is not singing with intonation precision, but does not possess the necessary vocal skills to sing the melody with intonation precision. The Educational Standards for the subject Music Education, in the form of educational outcomes, imply that the child should sing with intonation precision, in rhythm and tempo, with clear diction, articulation and expressive elements of music (Educational Standards, 2009, p. 5). Therefore, it is necessary, in the creation of "any assessment instrument, to bear in mind that they should provide information that will lead to 
further planning of teaching in the development vocal abilities" (Salvador, 2010, p. 45).

Starting from this statement, we have tried, based on the subject of our research, to determine the level of vocal skills of students of a younger primary school age, prior to and following the effect of the experimental factor. Good and Brophy (1997) suggest that teachers combine ways to assess the performance of music by singing. They suggest that teachers should combine the perceptual evaluation of intonation precision in singing songs, with other measures, such as using scales for the assessment of singing. Given that there is only a handful of experimental research in the field that we are dealing with, an assessment scale was constructed for the evaluation of vocal skills of second grade students of primary schools of general education (Jeremić, 2011, p. 281), based on the knowledge of tests for the assessment of musical abilities (tests by Seashore, Menerihg, Bentley, Marcel, Wing, Dykema) and insight into the work of Salvador (2010).

The vocal skills of students represent a complex concept that includes both musical skills and personality traits (cognitive and aesthetic). For these reasons, an experimental study of the effects of implementing methodical approaches in the processing of songs by ear requires a different approach, one that is both interdisciplinary and multidisciplinary. This is understandable because individual aspects of this research subject may at the same time be the research subject of several scientific disciplines. For example, remembering the teaching contents of the subject Music Education belongs to the field of intellectual education. Apfelstadt (1984) emphasizes the advantages of singing by heart for the purpose of achieving the vocal accuracy of tonal heights and precision singing, emphasizing the benefits of teaching which involves perception. The perceptual characteristics include singing by ear, timbre and melodiousness (Thorpe et al., 1999). The ability to memorize the melody and its perception leads to precise intonation in singing and to understanding the phenomenon of music. The selection and quality interpretation allow the song to be valued in an aesthetic sense. The performance of different songs while simultaneously enjoying in personal participation allows the student to express his or her personality, which belongs to the domain of psychology. The experience gained by this approach allows students to develop their creativity by simultaneously engaging in creative thinking, divergent thinking and convergent thinking. By nurturing the students' vocal techniques, we stimulate affective dispositions and the mastering of cognitive competencies. The students who feel insecure while singing can be helped by vocal training and instructions given by teachers, to a much greater extent (Aaron, 1992).

The main goal of this paper was focused on the overall phenomenon - the effect of implementing a methodical approach to the development of vocal skills and the effect of this phenomenon on an individual/student, in the real-life environment of the school/classroom. This type of approach is consistent with the holistic approach (Miles \& Huberman, 1984, p. 53) in terms of observing the phenomenon of vocal reproduction. 


\section{Methodology}

The aim of the research was to evaluate the methodical approach model in working with second grade students of general education primary schools, in teaching music performance by singing songs by ear and development of vocal skills (within the subject of Music Education). The level of knowledge achieved through the research aim relates to determining the developmental degree of the students' vocal skills following the implementation of the methodical model in the acquisition of a new song by ear. The practical aim of the research was to, based on the obtained results, point out the importance of implementing a methodical model in the development of not only vocal, but also musical skills of students in general, as well as to provide certain guidelines to teachers for working on the development of the students' vocal skills. From the aim of the research that was set forth, the following starting hypotheses were formulated.

$\mathrm{H}_{0}$ - There are statistically significant differences in the level of students' vocal skills based on the assessment of the development of: melodic hearing, musical memory, emotional sensitivity to musical impressions, sense of musical rhythm and quality of singing, between the students to whom the methodical model was applied (E - experimental group) and the students to whom the methodical model was not applied ( $\mathrm{C}$ - control group), in favour of the respondents from the experimental group, attributed to the methodical model of teaching.

The special hypothesis is as follows:

$\mathrm{H}_{1}$ - It is assumed that the students from the E group will achieve significantly better results when it comes to the level of vocal skills compared to the $\mathrm{C}$ group.

After eliminating the predictors that did not prove to be significant enough in the initial model, the following dependent variables of assessment remained: melodic hearing, musical memory, emotional abilities, musical rhythm and quality of singing. Since there were two measurements of these abilities (before and after the implementation of the methodical model), a design with repeated measures was applied. The independent variables in this research included: the vocal warm-up models based on the melodic and rhythmic elements of the songs that were processed and the methodical approach to the processing of a song by ear, i.e. the pedagogical-creative and methodical organization of the process of learning in the teaching of the subject Music Education at a younger school age.

Scaling was used as a research instrument. It was implemented by using the research technique Scale for the Assessment of Vocal Skills (Scaler - AVS), which was divided into five five-point subscales for expressing the level of agreement. The first subtest, which consisted of four items, examined the assessments of the melodic hearing of the students. The second subscale consisted of two items and examined the musical memory of the students. The third subscale consisted of three items and examined the emotional sensitivity, i.e. the affective sensitivity of the students. The assessment of the students' musical rhythm was examined by the fourth subscale which consisted 
of three items. The fifth subscale, which consisted of three items, examined the quality of the students' singing. The Scaler was constructed for the needs of this research and it measures vocal abilities of the students. The reliability of the instrument was measured by Cronbach's alpha coefficient $(\alpha=.931)$.

The musical conversation - interview, was conducted by the music teacher for half an hour with each student individually, thus avoiding them influencing each other and potentially providing repeat responses, given that the students were examined separately. Through this research technique, i.e. the procedure of oral examination on musical and non-musical issues, the facts relevant for the research subject were collected.

In order to examine the theoretical hypotheses, an experimental (causal) method with parallel groups (E - experimental and $\mathrm{C}$ - control) was used in the research. An experimental factor was introduced in the experimental group in the duration of one school year. In the control group a traditional model of teaching was applied. The data collected by the research were processed by using the descriptive statistical measures $\chi^{2}$-test, one-way and two-way analysis of variance. The general linear model was used for a comparative analysis of the vocal skills of the students in the $\mathrm{E}$ and $\mathrm{C}$ groups, in particular - the multivariate analysis of variance design with repeated measures (MANCOVA with repeated measures).

\section{Description of the experimental program}

In order to successfully realize the learning of a song by ear according to the methodical approach, an experimental program was designed. The purpose of this program was reflected in the realization of lessons in experimental classes in accordance with the methodical approach to learning songs by ear based on modelled teaching units. In order to determine the scientific reliability of the theoretical settings of the problems in teaching the subject of Music Education, and the criteria for the assessment of vocal skills of students that were derived from them, as well as the didactic-methodical approach in the realization of the content of processing songs by ear, we have tried to examine their influence on the development of vocal and, within the framework of the components that they define, musical skills as well. These are defined according to the parameters of the Scale for the Assessment of Vocal Skills of students and are made up of melodic hearing, musical memory, musical rhythm, emotional sensitivity and quality of singing of the students.

Vocal performance of music is the most represented form of active music production when it comes to second grade students of primary schools. In this sense, the experimental program was focused on the development of vocal skills of students by learning new songs by ear and it combined: a) a methodical approach to the processing of songs envisaged by the curriculum, by ear (Official Gazette of RS - Educational Gazette, Nos. 10/2004, 20/2004, 1/2005, 3/2006, 15/2006 and 2/2008), b) encouragement of the cultivation and development of vocal skills, and thus musical abilities in general, all with an aim of empowering the students for permanent engagement in music, c) 
student creativity, d) students' interest in valuable artistic and traditional works of music, e) solving tasks that unify the knowledge acquired by students in one class.

The elements of the experimental program are as follows:

a) Selection of teaching units with lessons containing the processing of songs by ear (realized in agreement with teachers whose classes participated in the research),

б) determination of the number and arrangement of teaching units,

в) determination of the structure and course of lessons,

г) detailed elaborates for lessons in the experimental program. As part of the experimental program, vocal warm-up models were designed and introduced. Based on the melodic structure of the songs, models were created that played the role of: 1 vocal warm-up in the sense of expanding the ambitus of the students' voices (transposition) and 2 vocal warm-up in the sense of tuning in with the tonality (with the tonality of the song). The vocal warm-up model contained several sub-models. In the models intended for tuning in with the tonality of the song, various melodic and rhythmic parts of the song being taught are prepared by gradual introduction of interval jumps. Their learning is realized in such a manner in which the teacher sings a certain submodel in tonality twice, and then students also repeat it twice. During the vocal warmup in the sense of expanding the ambitus of the students' voice when transposing a sub-model, the teacher sings the entire sub-model twice in the new tonality, and then the students also repeat it twice. Following the two transpositions of the sub-models, the teacher no longer presents the sub-model by his/her voice, but rather by intonation on an instrument, so that the initial tone of the sub-model is the highest note of the chord. If the vocal warm-up consists of transposition models, the new sub-model is always taught in the tonality and starting with the same tone with which the previous sub-model ended. The model always ends in the tonality of the song being taught. The tonalities of the models are conditioned by the tonality and ambitus of the song being taught. Their role is to widen the range of the students' voice, to nurture the vocal apparatus and develop the students' vocal technique. Different melodic exercises lead to the quicker adoption of a vocal technique and make the entire process interesting to students (Aaron, 1992). Models of vocal warm-ups are based on the melodic and rhythmic elements of the song that is taught, and they are always performed in the half soft dynamics (mezzo-piano). The syllables used in vocal warm-ups are as follows: ma, mo, mi, me, mu. They differ in each example and are consistent with the quantity of vocals $(a, e, i, o, u)$ in the literary text of the song itself. The aim of this approach in choosing syllables for vocal warm-ups is to prepare a clear vocalization and diction when singing a song that is learned by ear.

The structure of the lesson was determined by a model of methodical approach which contains a model of communication (Jeremić, 2012), a sequence model (Jeremić et al., 2015) and a voice warm-up model (Jeremić, 2015), and it encompassed the following stages:

1 motivational part that included solving certain tasks in order to repeat, consolidate knowledge and make an introduction to a new teaching unit; 
2 processing of the literary text of the song;

3 breathing exercises;

4 vocal preparation;

5 melodic rhythmic memorization of the new song according to the melodic wholes; 6 consolidation of the learned song.

This type of lesson structure is variable and should be viewed as a dynamic, open, flexible and adapted model. The articulation of the lesson is based on the methodical approach model of processing a song by ear and it is designed so as to imply an active student and a collaborative relationship between the teacher and the students.

\section{Sample description}

The research sample was comprised of second grade students of primary schools of general education: Primary School "Avram Mrazović" - Sombor (E II, E II $, \mathrm{E} \mathrm{II}_{4}, \mathrm{C}$ $\left.\mathrm{II}_{1}\right)$, Primary School "Vuk Karadžici" - Kikinda ( $\left.\mathrm{C} \mathrm{II}_{1}, \mathrm{C} \mathrm{II}_{2}\right)$. The total research sample consisted of three classes both in the experimental ${ }^{1}$ and control group ${ }^{2}$. The sample size was 129 students in the initial assessment. The change in the total sample number occurred due to the fact that the test for the assessment of vocal skills was conducted in a single day for each class (due to reliability) and some students were absent from classes on that day. Of the sample characteristics, only those that could have directly or indirectly influenced the results of the research were taken into account during the statistical processing of data (simplified models). The groups in the research were harmonized according to: gender structure of the control and experimental group sample which was similar $\left(\chi^{2}(1)=.007 ; \mathrm{p}=.934 ; \mathrm{N}=129\right)$, general academic achievement $-\chi^{2}$ was not statistically significant, so it can be said that the two groups did not differ in general academic achievement $\left(\chi^{2}(4)=7.791 ; \mathrm{p}=.100 ; \mathrm{N}=129\right)$, and achievement in the subject of Music Education $-\chi^{2}(3)=4.531 ; \mathrm{p}=.210 ; \mathrm{N}=129$ which was not statistically significant.

Based on the initial analysis of the results, it was concluded that, of the betweensubject effects, the main effects of affiliation with the experimental or control group $(\mathrm{p}<.003)$ proved to be significant. Followed by the main effect of gender $(\mathrm{p}<.24)$ and educational level of the fathers ( $\mathrm{p}<.17)$. Of the effects within respondents (repeated), only the effect of the interaction of measurement and group affiliation $(p<.000)$ was significant.

\section{Research results and discussion}

After eliminating the predictors that proved to be insignificant, the following dependent variables of assessment remained in the model: melodic hearing, musical memory, emotional sensitivity, musical rhythm and quality of singing.

\footnotetext{
${ }^{1}$ The experimental program was realized by the professor who is the author of the methodical approach

${ }^{2}$ In control group classes the teaching was conducted by homeroom teachers
} 
Jeremic and Stankovic: The Methodical Model of Teaching Songs by Ear and Its Effects on the Development of ...

Table 1

Results of the interaction of measurement and group affiliation (Multivariate tests)

\begin{tabular}{|c|c|c|c|c|c|c|}
\hline & Effect & $\begin{array}{c}\text { Wilks' } \\
\text { Lambda }\end{array}$ & $\mathrm{F}$ & $\begin{array}{c}\text { Hypothesis } \\
\text { df }\end{array}$ & $\begin{array}{c}\text { Error } \\
\mathrm{df}\end{array}$ & $\mathrm{p}$ \\
\hline \multirow{2}{*}{ 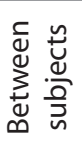 } & Segment & .100 & $180.392^{b}$ & 5.000 & 100.000 & .000 \\
\hline & Group & .792 & $5.248^{\mathrm{b}}$ & 5.000 & 100.000 & .000 \\
\hline \multirow{2}{*}{ 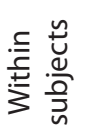 } & Measurement & .738 & $7.085^{\mathrm{b}}$ & 5.000 & 100.000 & .000 \\
\hline & $\begin{array}{l}\text { Measurement * } \\
\text { group }\end{array}$ & .574 & $14.872^{b}$ & 5.000 & 100.000 & .000 \\
\hline
\end{tabular}

In Table 1 it can be observed that the effect of the interaction of measurement and group affiliation is statistically significant; $p<.000$ signifying that, apart from the fact that the measured abilities are different in the two measurements, there are also differences between the two groups of respondents (that is, the abilities changed differently in the two measurements depending on group affiliation). This demonstrates that different methodical approaches give different results.

Since significant multivariate effects have been established, a univariate analysis of effects was undertaken in order to determine the abilities in which the groups differed, as well as the factors on which these differences depend.

Table 2

Review of the differences between groups in relation to dependent variables

\begin{tabular}{|c|c|c|c|c|c|c|}
\hline Source & Measurement & $\begin{array}{l}\text { Type III Sum } \\
\text { of Square }\end{array}$ & df & $\begin{array}{l}\text { Mean } \\
\text { Square }\end{array}$ & $\mathrm{F}$ & $\mathrm{p}$ \\
\hline \multirow{5}{*}{ Measurement } & melodic hearing & 10.896 & 1 & 10.896 & 4.736 & .032 \\
\hline & musical memory & 1.128 & 1 & 1.128 & .978 & .325 \\
\hline & emotional sensitivity & 6.958 & 1 & 6.958 & 3.784 & .054 \\
\hline & musical rhythm & 24.063 & 1 & 24.063 & 12.233 & .001 \\
\hline & quality of singing & 53.610 & 1 & 53.610 & 30.561 & .000 \\
\hline \multirow{5}{*}{$\begin{array}{l}\text { Measurement * } \\
\text { group }\end{array}$} & melodic hearing & 95.535 & 1 & 95.535 & 41.523 & .000 \\
\hline & musical memory & 20.570 & 1 & 20.570 & 17.834 & .000 \\
\hline & emotional sensitivity & 40.267 & 1 & 40.267 & 21.899 & .000 \\
\hline & musical rhythm & 31.573 & 1 & 31.573 & 16.051 & .000 \\
\hline & quality of singing & 124.025 & 1 & 124.025 & 70.703 & .000 \\
\hline \multirow{5}{*}{$\begin{array}{c}\text { Error } \\
\text { (measurement) }\end{array}$} & melodic hearing & 239.278 & 104 & 2.301 & & \\
\hline & musical memory & 119.957 & 104 & 1.153 & & \\
\hline & emotional sensitivity & 191.231 & 104 & 1,839 & & \\
\hline & musical rhythm & 204.579 & 104 & 1,967 & & \\
\hline & quality of singing & 182.435 & 104 & 1,754 & & \\
\hline
\end{tabular}

The data in Table 2 demonstrate that, if group affiliation is not taken into account in the two measurements, the investigated factors related to the implementation of the 
methodical model change significantly, as follows: melodic hearing $\mathrm{F}(1) 4.736 ; \mathrm{p}=.032$ musical rhythm $\mathrm{F}(1) 12.233 ; \mathrm{p}=.001$ and quality of singing $\mathrm{F}(1) 30.561 ; \mathrm{p}=.000$. However, group affiliation alters the direction of the change, i.e. all of the investigated factors related to the development of vocal skills after the implementation of the methodical model have changed to a different degree between the two measurements, depending on group affiliation. Based on these results, it can be concluded that the methodical model had influenced the obtained results, confirming the general hypothesis ( $\mathrm{H} 0)$.

Table 3

Review of the differences within research groups in terms of the students' vocal skills

\begin{tabular}{cccccccc}
\hline \multicolumn{7}{c}{ Transformation of the variable: average } \\
\hline source & Measurement & $\begin{array}{c}\text { Type III Sum } \\
\text { of Squares }\end{array}$ & df & \multicolumn{1}{c}{$\begin{array}{c}\text { Mean } \\
\text { Square }\end{array}$} & $\mathrm{F}$ & $\mathrm{p}$ \\
& melodic hearing & 9079.799 & 1 & 9079.799 & 327.853 & .000 \\
& musical memory & 2128.402 & 1 & 2128.402 & 273.971 & .000 \\
& emotional sensitivity & 8059.878 & 1 & 8059.878 & 885.650 & .000 \\
& musical rhythm & 6450.372 & 1 & 6450.372 & 391.374 & .000 \\
& quality of singing & 7729.419 & 1 & 7729.419 & 349.279 & .000 \\
\hline \multirow{2}{*}{ Group } & melodic hearing & 346.365 & 1 & 346.365 & 12.507 & .001 \\
& musical memory & 81.160 & 1 & 81.160 & 10.447 & .002 \\
& emotional sensitivity & 49.644 & 1 & 49.644 & 5.455 & .021 \\
& musical rhythm & 368.499 & 1 & 368.499 & 22.359 & .000 \\
& quality of singing & 209.229 & 1 & 209.229 & 9.455 & .003 \\
\hline \multirow{2}{*}{ Error } & melodic hearing & 2880.255 & 104 & 27.695 & & \\
& musical memory & 807.945 & 104 & 7.769 & & \\
& emotional sensitivity & 946.454 & 104 & 9.101 & & \\
& musical rhythm & 1714.059 & 104 & 16.481 & & \\
& quality of singing & 2301.480 & 104 & 22.130 & & \\
\end{tabular}

The results shown in Table 3 demonstrate a significant difference in relation to the observed abilities of the control and experimental group, taking into account the average of the two measurements.

The applied methodical model has significantly influenced the development of the vocal skills of the experimental group as can be seen in the comparison of the results on the initial and final measurement (Table 4).

Table 4

Review of the level of vocal skills of the experimental group in relation to the initial and final measurement

\begin{tabular}{ccccc}
\hline \multirow{2}{*}{ MEASUREMENT } & \multirow{2}{*}{$\mathrm{M}$} & \multirow{2}{*}{$\mathrm{SE}$} & \multicolumn{2}{c}{$95 \%$ confidence interval } \\
\cline { 4 - 5 } & & & lower bound & upper bound \\
\hline 1 & 50.090 & 1.400 & 47.318 & 52.863 \\
2 & 54.091 & 1.313 & 51.490 & 56.692 \\
\hline
\end{tabular}

The data show (Table 5) that higher levels of vocal skills have been calculated when it came to students from the experimental group, which is also demonstrated 
by a drop in the mean value when it came to students from the control group in the final measurement. Based on the presented data, it can be concluded that the vocal skill potentials that exist may weaken and/or disappear if not encouraged, primarily because the students covered by this research are of the age that represents the upper limit when it comes to the possibility to influence the development of their vocal skills. Based on the above, the $\mathrm{H}_{1}$ hypothesis has been confirmed.

Table 5

Review of the level of vocal skills of the research groups

\begin{tabular}{ccccc}
\hline Group & M & Std. error & \multicolumn{2}{c}{$95 \%$ confidence interval } \\
& & & lower bound & upper bound \\
\hline Experimental & 56.548 & 1.809 & 52.965 & 60.130 \\
Control & 47.634 & 1.919 & 43.834 & 51.434 \\
\hline
\end{tabular}

In Table 6 it can be seen that the effect of the interaction between measurement and affiliation with the control or experimental group is significant $\mathrm{F}(1)=11.424 ; \mathrm{p}=.001$ and these results support the assumption that the implemented methodical model will influence the development of the students' vocal skills.

Table 6

Effects of measurement and affiliation with the control or experimental group

\begin{tabular}{cccccc}
\hline Source & \multicolumn{5}{c}{$\begin{array}{c}\text { Variable transformation: } \\
\text { grade level }\end{array}$} \\
\hline & Sum of Squares & df & M & F & p \\
\hline Segment & 643566.190 & 1 & 643566.190 & 1560.590 & .000 \\
Group & 4711.148 & 1 & 4711.148 & 11.424 & .001 \\
Statistical error & 48249.205 & 117 & 412.386 & & \\
\hline
\end{tabular}

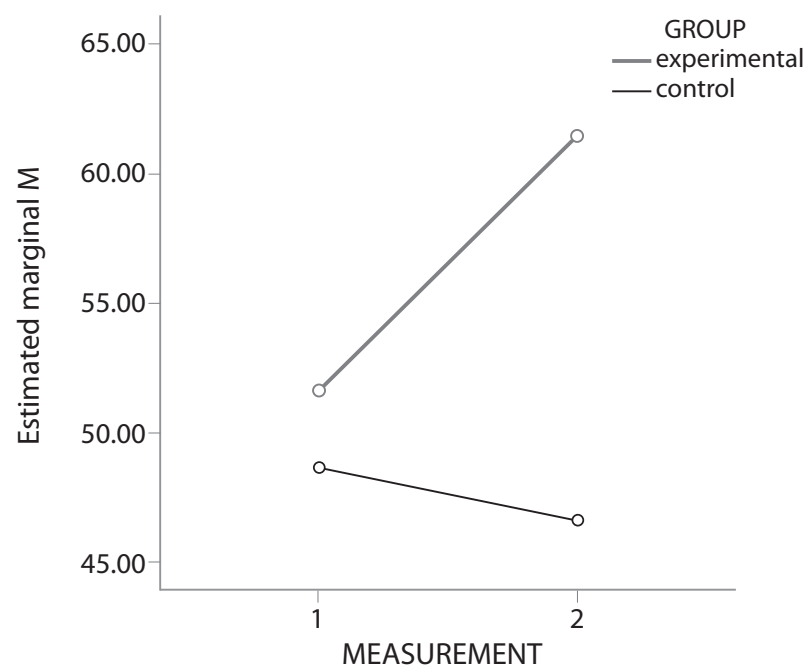

Figure 1. Impact of the implemented teaching method on the development of vocal skills 
In Figure 1, the initial and final levels of vocal skills in both groups can be observed. After the implementation of the methodical model, an increase was recorded regarding all of the measured skills in the experimental group. The control group has, however, demonstrated a drop in the measured skills - emphasizing, again, that the teaching in the control group took place without the implementation of the methodical model.

The assessment of the vocal skills of students included tests related to the development of melodic hearing, sense for musical rhythm, musical memory, emotional sensitivity to musical impressions and quality of singing. Influenced by the experimental factor, the respondents have achieved better results according to the parameters of the Scale for the AVS, thus confirming the special $\mathrm{H}_{1}$ hypothesis. By reviewing the descriptive statistics related to the vocal skills by groups, it can be observed that the experimental group achieved higher scores in relation to the control group, in both measurements. This is an indication that vocal skills, if not developed, disappear, and it is precisely this age that represents the upper limit for influencing their development.

The results concerning the interaction between measurement and group affiliation $(\mathrm{F}(1)=5.248 \mathrm{p}=.000$ (Table 1), the difference between groups in relation to the dependent variables $(F(1)=41.523 ; p=.000$ (Table 2 ), the level of vocal skills when considering the average of the two measurements between the research groups $F(1)=12.507 ; p=.001$ (Table 3), as well as the arithmetic means of the level of vocal skills of the research groups - the arithmetic mean of the experimental group equals 56.548, while the arithmetic mean of the control group equals 47.634 (Table 4), demonstrate that the experimental group had higher scores on all observed parameters. Also, the review of the level of vocal skills of the research groups, the arithmetic mean for the experimental group equals 56.548, while the arithmetic mean for the control group equals 47.634 (Table 5), speaks in favour of the experimental group and the implemented methodical approach. The tests of effects within respondents indicate that the two groups differ in the level of vocal skills when considering the average of the two measurements $\mathrm{F}(1)=11.424 ; \mathrm{p}=.001$ (Table 6 ) - and therefore, it can be concluded that the general $\mathrm{H}_{0}$ hypothesis has been confirmed.

It should be emphasized that, during the experimental program, the students made significant progress, especially when it came to the parameter of sensitivity for intonation precision. In this sense, the methodical approach that involved reproduction, interpretation and analysis of the teaching contents led students to an active knowledge of music, whereby the acquisition of knowledge was based on musical experience and the quality of acquired knowledge. The individual structure of teaching units, vocal preparation, physical and emotional empathy, melodic and rhythmic memorization of songs, represent elements of an innovative methodical approach to the acquisition of songs by ear, and its implementation leads to the expression of perception, affective responses and reproduction at a higher level.

The results of the implementation of the experimental program and the music content of the songs have influenced the possibility of expressing the personal identity 
and emotions of the students, thanks to the higher quality of vocal performance. Furthermore, the students have developed the ability to accurately respond to various tonal heights, tonal characteristics, dynamics, the sense of harmonic coherence expressed in the harmonic basis of the vocal warm-up model. The students from the experimental group have gained a finely-tuned auditory perception, as well as oralsensory feedback, which is precisely what represents the basic teaching tool in the teaching field of performing music by singing.

\section{Concluding Remarks}

In the pedagogical practice of music there are several methodical approaches to the acquisition of songs by ear (Brdarić 1986; Rojko, 2004; Požgaj, 1988; Plavša, 1989). In this study, an attempt was made to determine the effects of the implementation of a methodical approach and model in the processing of songs by ear on the development of vocal abilities.

The scope of this research has been influenced, as previously mentioned in the theoretical section of this paper, by the still modest scientific foundation in a very significant field of music education. The lack of similar studies, both in our country and abroad, has deemed scientific verification and comparison of the results of our research impossible. Following the testing of the hypotheses, it can be said that the goal of the research has been achieved, due to the fact that it has been established that the methodical approach to the acquisition of songs by ear has shown better results in the experimental group than in the control group. The implementation of research procedures in our experiment bore certain problems. The most important task was to devise a way and determine a measure for the assessment of the students' vocal skills. Namely, according to Radoš (2010, p. 48), the level and quality of musical skills are assessed by music teachers through tasks requiring the manifestation of the most basic aspects of these skills. The assessment or examination of any kind of musical skill requires a certain measurement and experimental verification or evaluation of the program itself. However, a small number of attributes have been included in the examination (most music teachers, according to Radoš (2010, p. 48), agree that the basic attributes of musical skills are reproduction and vocal performance of songs), and it is therefore impossible to determine the level of musical skills with certainty and precision. Furthermore, the conditions in which the examination was conducted and subjectivity in oral examinations largely preclude the exact comparison of the results obtained. In addition to these shortcomings, the duration of the examinations also became an issue, as it concerned the research procedure of conducting interviews.

Based on the analysis of the achieved results, it is believed that the experimental (independent) variable has influenced the development of the students' vocal skills. The assumption is that it has also influenced the development of their individual music skills, their critical and creative approach to music, the development of cognitive processes and the cultivation of the general music education of students. 
The effect of implementing the methodical approach model to the acquisition of songs by ear is the active knowledge of the aesthetic qualities of music. This knowledge begins only when a student is able to connect the knowledge about music with the sound or a song that he or she is listening to and singing. Different musical experiences, especially the performance of music by singing or playing, enable students to become familiar with the phenomenon of music.

The experimental program has demonstrated a sort of musical maturation of the respondents, a higher level of success in gaining knowledge about music and a deeper level of musical understanding. A tangible model was developed, in which the processing of songs by ear according to the methodical model and spontaneous learning, primarily enable the understanding of music on an emotional level, as well as the awareness of the learned elements of music (melody, rhythm, form) in the process of achieving musical literacy.

It is believed that this paper, by emphasizing the significance of the development of vocal skills, can become a guideline towards directing the interests and cultivating the musical taste of students. The most significant and simplest way to develop musical dispositions in students is precisely to encourage quality singing with elements of vocal techniques, which creates the conditions for the development of love and a need for a permanent engagement in quality music. We cannot expect an understanding of art and music from students who are not allowed to engage in them, to sing and develop the skills to perceive and understand music.

Without the abilities of affective responding, which are manifested through the development of vocal skills at a younger school age, there is no inspiration, no art, no teaching process in which knowledge is acquired by discovering music and the laws that govern music.

\section{References}

Aaron, J. (1992). Effects of vocal coordination instruction on the pitch accuracy, range, pitch discrimination, and tonal memory of inaccurate singers. Paper presented at the Music Educators National Conference National Convention Poster Session, New Orleans, LA.

Apfelstadt, H. (1984). Effects of melodic perception instruction on pitch discrimination and vocal accuracy of kindergarten children. Journal of Research in Music Education, 32, 15-24. https://doi.org/10.2307/3345277

Bačlija Sušić, B. (2015). Temeljni aspekti kognitivnih modela djetetova glazbenog razvoja [Fundamental aspects of cognitive models of a child's musical development]. Napredak. (1-2), 33-53.

Brdarić, R. (1986). Pripremanje nastavnika za nastavu glazbene kulture. Školska knjiga.

Good, T., L., \& Brophy, J., E. (1997). Looking in classrooms (7th ed.). Longman. 
Jeremić and Stankovic: The Methodical Model of Teaching Songs by Ear and Its Effects on the Development of ...

Jarjisian, C. S. (1981). The effects of pentatonic and/or diatonic pitch pattern instruction on the rote-singing achievement of young children. Dissertation Abstracts International, 42, 2015 A. (University Microfilms No. 8124581).

Jeremić, B. (2011). Darovitost, talenat i kreativnost - odrednice. [Giftedness, Talent and Creativity - Guidelines]. Obrazovna tehnologija, XII (3), 277 - 286.

Jeremić, B. (2012). Model komunikacije tokom horskog izvođenja [Model of Communication in Choral Performance]. Nastava i vaspitanje. LXI(2) 333 - 350.

Jeremić, B., Šimonji-Cernak R., Markov Z., \& Pantić J. (2015). The Effects of Methodical Approach to Vocal Performance on the Social-Emotional Competencies of the Early School-Age Children. Croatian Journal of Education. Vol. 17; Sp. Ed. No. 3, 151-185. https:// doi.org/10.15516/cje.v17i0.1125

Jeremić, B. (2015). Od pevanja do muzičke kulture - Metodika nastave muzičke kulture. [From Singing to Music Education - Music Education Teaching Methods]. Sombor: Pedagoški fakultet.

Jurkić Sviben, T., \& Margetić, N. (2013). Differences in Opinion about the Type of Education Necessary to Implement Music Teaching in View of Song Teaching Variants. Croatian Journal of Education, 15 (Sp.Ed.1), 111-126.

Miles, M., B., \& Huberman, A. M. (1984). Qualitative Data Analysis: An Expanded Sourcebook, Sage.

Požgaj, J. (1988). Metodika nastave glazbene kulture u osnovnoj školi. Školska knjiga.

Plavša, D. (1989). Muzičko- pedagoške dileme i teme. Akademija umetnosti.

Radoš-Mirković, K. (1998). Психологија музичких способности [Psychology of Musical Skills]. Zavod za udžbenike i nastavna sredstva.

Radoš, K. (2010). Psihologija muzike [Psychology of Music]. Zavod za udžbenike i nastavna sredstva.

Rojko, P. (2004). Metodika glazbene nastave - praksa 1. Dio. J. Zlatar.

Salvador, K. (2010) How Can Elementary Teachers Measure Singing Voice Achievement? A Critical Review of Assessments, 1994-2009. Applications of Research in Music Education, 29(1), 40-47. https://doi.org/10.1177/8755123310378454

Thorpe, C., W., Callaghan, J., \& van Doorn, J., L. (1999). Visual Feedback of Acoustic Voice Features for the Teaching of Singing', Australian Voice, 5, 32-39.

Welch, G. F. (2005). Singing as communication. In D. Miell, MacDonald, R. \& Hargreaves D.J. (Eds.), Musical Communication. (pp. 239-261). Oxford University Press. https://doi. org/10.1093/acprof:oso/9780198529361.003.0011

Woody, R. H. (2012). Playing by Ear: Foundation or Frill? Music Educators Journal, 99(2), 82-88. https://doi.org/10.1177/0027432112459199

Official Gazette of RS - Educational Gazette, Nos. 10/2004, 20/2004, 1/2005, 3/2006, 15/2006 and 2/2008. http://mirjanamilic.files.wordpress.com/2011/10/nastavni-program-za-1i-2-razred.pdf

Education standards for the end compulsory education. (2009). Ministry of Education of the Republic of Serbia, Institute for the Evaluation of Education Quality 


\section{Biljana Jeremić}

Department of Methodology of Music and Art Culture and Physical Education

Faculty of Education in Sombor

University of Novi Sad

Podgorička 4, 25000 Sombor, Serbia

biljana.jeremic@pef.uns.ac.rs

\section{Emilija Stanković}

Department of Music

Academy of Arts

University of Novi Sad

Djure Jaksica 7, 21000 Novi Sad, Serbia

emast59@gmail.com 


\section{Metodički model poučavanja pjesama po sluhu i učinci njegova utjecaja na razvoj učeničkih glasovnih sposobnosti}

\section{Sažetak}

Svrha je ovoga rada provjeriti istraživani fenomen (primjena modela vježbi vokalnog zagrijavanja, kao i osmišljen i planski metodički pristup učenju pjesme po sluhu) eksperimentom s paralelnim skupinama. Predmet je ovog istraživanja utvrditi je li moguće utjecati na kvalitetu pjevanja i razvijati glasovne sposobnosti učenika mlađeg uzrasta planiranim i usmjerenim metodičkim pristupom za učenje pjesama po sluhu. Kako bi se provjerili učinci provedbe metodičkog modela, korišten je SPVS instrument (Skala provjere vokalnih sposobnosti, Jeremić, 2011: 281), subtest I, II, III, IV i V (ekvivalentni oblik početnog i završnog testiranja). Za usporedbu skupina po glasovnim sposobnostima korišten je opći linearni model, a osobito multivarijacijska analiza kovarijanata s ponovljenim mjerenjima (MANCOVA s ponovljenim mjerenjima). Uzorak ovog istraživanja činili su učenici drugog razreda osnovnih škola u Somboru i Kikindi, u Srbiji. Testovi učinaka unutar ispitanika pokazuju da se dvije skupine razlikuju po razini vokalnih sposobnosti pri promatranju prosjeka dvaju mjerenja $F(1)=11.424, p=.001$.

Ključne riječi: metodika; glazbeno obrazovanje; pjevanje; učenici mlade dobi 